\title{
Erratum to: 'The direction of cross affects obesity after puberty in male but not female offspring'
}

Stefan Kärst ${ }^{1 \dagger}$, Danny Arends ${ }^{1 \dagger}$, Sebastian Heise ${ }^{1 \dagger}$, Jan Trost ${ }^{1}$, Marie-Laure Yaspo ${ }^{2}$, Vyacheslav Amstislavskiy ${ }^{2}$, Thomas Risch², Hans Lehrach ${ }^{2}$ and Gudrun A. Brockmann ${ }^{1 *}$

Unfortunately, the original version of this article [1] contained an error. The title was written incorrectly 'The direction of cross obesity after puberty in male but not female offspring'. The title has been corrected in the original article and is also included correctly above.

\section{Author details}

'Albrecht Daniel Thaer-Institut für Agrar- und Gartenbauwissenschaften, Humboldt-Universität zu Berlin, Invalidenstraße 42, Berlin D-10115, Germany. ${ }^{2}$ Max Planck Institute for Molecular Genetics, Gene Regulation and Systems Biology of Cancer, Ihnestraße 63-73, Berlin 14195, Germany.

Received: 10 November 2015 Accepted: 10 November 2015

Published online: 30 November 2015

\section{Reference}

1. Kärst S, Arends D, Heis S, Trost J, Yaspo ML, Amstislavskiy V, et al. The direction of cross affects obesity after puberty in male but not female offspring. BMC Genomics. 2015;16:904.

\footnotetext{
* Correspondence: gudrun.brockmann@agrar.hu-berlin.de

${ }^{\dagger}$ Equal contributors

'Albrecht Daniel Thaer-Institut für Agrar- und Gartenbauwissenschaften, Humboldt-Universität zu Berlin, Invalidenstraße 42, Berlin D-10115, Germany Full list of author information is available at the end of the article
}

Submit your next manuscript to BioMed Central and take full advantage of:

- Convenient online submission

- Thorough peer review

- No space constraints or color figure charges

- Immediate publication on acceptance

- Inclusion in PubMed, CAS, Scopus and Google Scholar

- Research which is freely available for redistribution

Submit your manuscript at www.biomedcentral.com/submit 